\title{
Active heterotrophic nanoflagellates in the hypoxic water-column of the eutrophic Masan Bay, Korea
}

\author{
Jong S. Park, Byung C. Cho* \\ School of Earth and Environmental Sciences and Research Institute of Oceanography, Seoul National University, \\ Seoul 151-742, Korea
}

\begin{abstract}
To investigate if heterotrophic nanoflagellates (HNF) in the hypoxic zone of the coastal water-column were actively grazing on bacteria, and to understand what factors were controlling HNF in the hypoxic zone, field work was carried out in summer 1999 in the eutrophic Masan Bay, Korea. Samples ranging from 0.22 to $3.87 \mathrm{mg} \mathrm{O}_{2} \mathrm{l}^{-1}$ were assayed in chambers in which oxygen concentration was adjusted with $\mathrm{N}_{2}$ gas to the in situ $\mathrm{pO}_{2}$ of samples. Ratios of HNF-to-bacteria abundance varied from 6 to $31 \times 10^{-5}$ in the hypoxic zone, and those at the surface usually ranged from 7 to $33 \times 10^{-5}$, with some high values $\left(46\right.$ to $115 \times 10^{-5}$ ) observed in August. Biomass-carbon ratios of HNF-to-bacteria varied from 1.0 to $6.9 \times 10^{-2}$ in the hypoxic zone and were generally 2 - to 3 -fold lower in the hypoxic zone than at the surface. Biovolumes of HNF in the hypoxic zone (6 to $24 \mu \mathrm{m}^{3}$ ) were mostly similar to those in the surface layer. Interestingly, per cell clearance rates of hypoxic HNF were statistically higher than or similar to those in the surface layer. Thus, an active microbial loop seemed to operate in the hypoxic zone as well. Aeration of hypoxic samples to oxygen saturation did not cause any significant changes in grazing rates of hypoxic HNF, indicating non-susceptibility of hypoxic HNF to changes in oxygen exposure. It seems that most HNF in the hypoxic zone used aerobic metabolism. Further, incubation of hypoxic HNF with temperatures 4 to $6^{\circ} \mathrm{C}$ greater and lower than in situ temperature resulted in a low $Q_{10}$ value (1.6) in HNF grazing rate in the hypoxic sample compared to the $Q_{10}$ value (3.2) in the surface sample. This shows the significantly different response of HNF to temperature in the hypoxic zone. The positive relationship of the HNF grazing rate with bacterial abundance in the hypoxic zone suggests that HNF were largely controlled by bacterial availability.
\end{abstract}

KEY WORDS: Heterotrophic nanoflagellates $\cdot$ Hypoxia $\cdot$ Grazing rate $\cdot$ Masan Bay Resale or republication not permitted without written consent of the publisher -

\section{INTRODUCTION}

Hypoxic conditions (<4 mg O $\mathrm{I}^{-1}$; Paerl et al. 1998) in coastal waters are nowadays widely observed in fjords, coastal and estuarine waters, and are expected to increase (Seki 1991, Malakoff 1998, Nestlerode \& Diaz 1998). However, in spite of many environmental concerns on occurrences of hypoxia (Malakoff 1998, Paerl et al. 1998), studies on the microbial ecology of hypoxic marine waters are surprisingly rare (Fenchel et al.

*E-mail: bccho@plaza.snu.ac.kr
1995, Choi et al. 1999). A few studies report abundant distributions of protozoa and bacteria in the hypoxic zone (Gast \& Gocke 1988, Fenchel et al. 1990, Detmer et al. 1993, Choi et al. 1999).

Heterotrophic nanoflagellates (HNF) are the major grazers of bacteria in surface waters in various marine environments (Pedrós-Alió et al. 2000), and they play an important role in transferring bacterial biomass to higher trophic levels (Fenchel 1982b, González et al. 1990, Sherr \& Sherr 1994). However, measurements of HNF grazing rates on bacteria in hypoxic marine water samples are quite rare. A study done in micro-aerophilic water of Lake Vechten (Bloem \& Bär-Glissen 
1989) using fluorescently labeled bacteria reported that HNF ingestion rates ranged from 2 to 17 bacteria $\mathrm{HNF}^{-1} \mathrm{~h}^{-1}$. Observations of similar abundance and biomass ratios of HNF to bacteria between the surface and hypoxic zone during a strong stratification period also suggested that HNF in the hypoxic zone are actively grazing on bacteria (Choi et al. 1999).

In marine environments, HNF grazing rates are known to be regulated by temperature, bacterial abundance and production (Peters 1994, Vaqué et al. 1994). Low-oxygen conditions might be considered as a controlling factor. However, the relationship between half-saturation $\mathrm{pO}_{2}$ for respiration of different organisms and their linear dimensions (Fenchel \& Finlay 1995) predicts that oxygen concentrations down to ca. 0.1 at. sat. \% would not affect HNF activity.

The goals of this study were to measure grazing rates of HNF in the hypoxic zone of coastal waters and to identify regulatory factors on HNF in the hypoxic zone. We measured HNF grazing rates on bacteria of the hypoxic samples in chambers in which oxygen concentration was adjusted with pure $\mathrm{N}_{2}$ gas to the in situ $\mathrm{pO}_{2}$ of water samples. We also carried out experiments on aeration and temperature responses of HNF to evaluate the effects of oxygen saturation and temperature on HNF in the hypoxic zone of coastal waters, respectively.

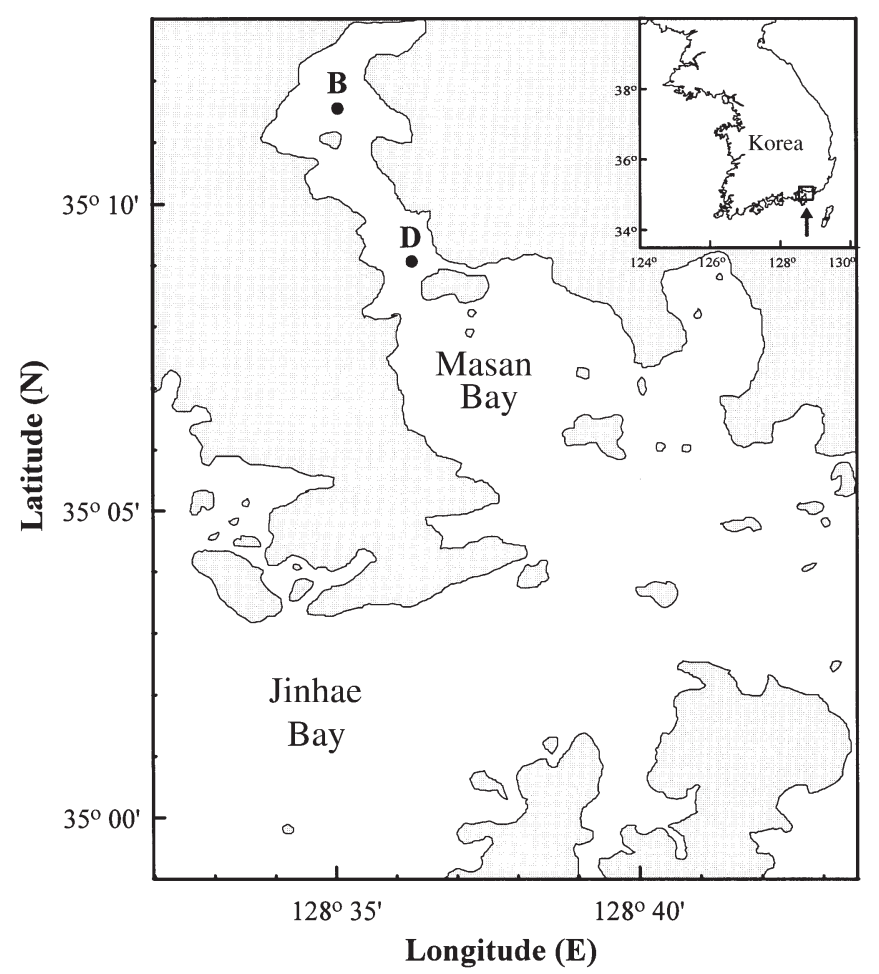

Fig. 1. Study area and sampling stations in Masan Bay, Korea

\section{MATERIALS AND METHODS}

Hypoxia. There are some variations among investigators in defining hypoxia in marine environments. For example, Paerl et al. (1998) considered estuarine water hypoxic to occur where the dissolved oxygen (DO) concentration was below $4 \mathrm{mg} \mathrm{O}_{2} \mathrm{l}^{-1}$. DO concentration below $5 \mathrm{mg} \mathrm{O}_{2} \mathrm{l}^{-1}$ in Chesapeake Bay was regarded to be hypoxic by Park et al. (1996). In another classification, hypoxic coastal water had a DO concentration between 0.036 and $3.6 \mathrm{mg} \mathrm{O}_{2} \mathrm{l}^{-1}$ (Seki 1991). Such definitions include a micro-aerobic condition $(0.1$ to 5 at. sat. \%, Fenchel \& Finlay 1995). As some protozoa and bacteria are known to be adapted to the micro-aerobic condition (Seki et al. 1984), and as our aim was to study the characteristics of HNF in the hypoxic zone, a range of 0.4 to $4.0 \mathrm{mg} \mathrm{O}_{2} \mathrm{l}^{-1}$ (or 5 to $50 \%$ DO saturation) was regarded as the hypoxic condition in our study, and a range of 0.1 to $5 \%$ DO saturation was regarded as the micro-aerobic condition (as according to Fenchel \& Finlay 1995).

Study area and sample collection. The Masan Bay (Fig. 1) located on the southern coast of Korea is a semi-enclosed inner bay with an area of $33.8 \mathrm{~km}^{2}$ and an average depth of ca. $15 \mathrm{~m}$. The bay is highly eutrophic due to inputs of municipal sewage from Masan city and industrial wastes from the industrial complex in the city. Hypoxia is usually found during summertime every year, and often anoxia develops in the bottom layer in late summer (Chung et al. 1999). During 4 investigations in summer 1999 in Masan Bay, seawater samples were collected with 51 Niskin bottles. Depth profiles of in situ DO concentration were measured in the field by lowering an oxygen probe (YSI 58 DO meter). The oxygen probe was calibrated with air at $100 \%$ according to the the instructions provided. DO concentrations determined by the oxygen probe were well correlated with those determined by Winkler method $\left(\mathrm{r}^{2}=0.9, \mathrm{p}<0.01, \mathrm{n}=12\right.$; data not shown). To avoid introducing oxygen during handling, hypoxic samples were gently drained from the Niskin bottle with silicon tubing to 21 biological oxygen demand (BOD) bottles, which were overflowed. Samples from the hypoxic zone were kept ca. $2 \mathrm{~h}$ at in situ temperature before experiments started in the land-based laboratory. We checked the DO concentration of the samples in the laboratory before carrying out experiments and found no significant change of DO due to handling. Each sample was used for determining HNF abundance, HNF grazing rates on bacteria, and bacterial abundance.

Abundances of bacteria and HNF, and grazing rates of HNF. Samples for measurements of bacterial abundance were preserved with $0.2 \mu \mathrm{m}$ filtered, boratebuffered formalin (final conc. of $2 \%$ ). Bacteria, stained with DAPI $\left(4^{\prime}, 6^{\prime}\right.$-diamidino-2-phenylindole) and col- 
lected on black $0.2 \mu \mathrm{m}$ polycarbonate filter, were counted under UV excitation using an epifluorescence microscope (Porter \& Feig 1980). Samples for measurements of HNF abundance were preserved immediately with alkaline Lugol solution (final conc. of $0.5 \%$ ) and borate-buffered formalin (final conc. of 3\%, Sherr et al. 1989; Rassoulzadegan 1991). Primulin-stained HNF collected on $0.4 \mu \mathrm{m}$ polycarbonate filters ( $25 \mathrm{~mm}$ diameter) at a vacuum not exceeding $100 \mathrm{~mm} \mathrm{Hg}$ were enumerated at $\times 1000$ magnification with UV excitation using an epifluorescence microscope (Bloem et al. 1986). Between 10 and $15 \mathrm{ml}$ of seawater was filtered. During counting, the length of the short and long axes of HNF was measured with eyepiece reticules and recorded for biovolume calculations. HNF grazing rates on bacteria were measured by using fluorescently labeled bacteria (FLB) prepared according to Sherr et al. (1987). Briefly, FLB were prepared by staining natural bacterial samples collected from coastal waters with 5-(4,6-dichlorotriazin-2yl) aminofluorescein (DTAF). The biovolumes of FLB and bacteria were determined by microphotographs and slides projected onto a paper screen (Cho et al. 2000). Mean FLB biovolumes $\left(0.084 \pm 0.014 \mu^{3}\right)^{3}$ were in most cases similar to in situ mean bacterial biovolumes (0.091 $\pm 0.024 \mu^{3}$ ). In 2 samples from Stn B (5 m depth, June; $1 \mathrm{~m}$ depth, late August), mean FLB biovolumes were larger (1.6- to 1.9-fold) than the in situ mean bacterial biovolume. Carbon biomass of HNF was calculated by multiplying biovolume of HNF by a conversion factor of $220 \mathrm{fg} \mathrm{C} \mu^{-3}$ (Børsheim \& Bratbak 1987), and bacterial carbon was calculated using bacterial biovolumes according to Simon \& Azam (1989).

FLB uptake experiments were carried out in duplicate in $250 \mathrm{ml}$ polycarbonate bottles presoaked in $10 \%$ (vol./vol.) $\mathrm{HCl}$ and copiously rinsed with deionized water. The added concentration of FLB was between 4 and $14 \%$ of bacterial abundance. Grazing experiments were conducted in the dark at in situ temperature and in situ oxygen concentration. In the laboratory, we handled hypoxic samples inside a chamber for measurements of HNF grazing. Oxygen concentration in a chamber, constructed in a manner like an anaerobic chamber, was adjusted by pure $\mathrm{N}_{2}$ gas to in situ DO \% saturation. Inside the chamber, oxygen concentration was monitored by an oxygen probe (Model XO-326AL, New Cosmos Electric). Thus, precise control of in situ DO \% saturation in the air of the chamber was possible, allowing HNF grazing assays in hypoxic conditions. During the experiments, no significant change in oxygen concentration was found in the chamber. Thirty ml of subsamples were collected at 0,10, 20 and $30 \mathrm{~min}$, fixed, and kept refrigerated until microscopic examinations. Subsamples were primulin stained and filtered, and at least 150 microscopic fields were counted. The filters were first observed under UV exci- tation at a magnification of $\times 1000$. When an HNF was located, the incident light was switched to blue and the numbers of FLB contained within the HNF were counted. According to Sherr et al. (1987), we calculated per cell clearance rates and grazing rates: FLB uptake rates were calculated from the changes in average number of FLB cell ${ }^{-1}$ with time using simple regression analysis. Per cell clearance rates $\left(\mathrm{nl} \mathrm{HNF}^{-1} \mathrm{~h}^{-1}\right.$ ) were calculated by dividing the cell-specific uptake rates of FLB by the concentration of FLB per nl. Average values of per cell clearance rates were calculated for duplicate bottles. Grazing rates were calculated by multiplying the per cell clearance rates by the total bacterial abundance and the HNF abundance in the samples. Bacterivory rates were measured over the linear portion of the uptake curve and the uptake was linear for ca. 30 min. The ranges of $\mathrm{CV}(=100 \times \mathrm{SD} / \mathrm{mean})$ of the slopes from duplicate bottles were 3 to $26 \%$ (mean \pm SD of $13.9 \pm 7.9 \%)$. The volume-specific clearance rates $\left(\mathrm{h}^{-1}\right)$ were calculated by dividing the per cell clearance rates by the biovolume of HNF.

We further carried out aeration experiments to test whether HNF of hypoxic waters were affected by oxygen saturation. Samples from the hypoxic zone were aerated with particle free, filtered $(0.2 \mu \mathrm{m})$ air to between 95 and $100 \%$ air saturation. Oxygenation took $<2 \mathrm{~h}$. Then, HNF grazing rates were measured as described above. The aeration treatment might sometimes lead to cell destruction or lower activity of a certain group of protozoa, but we did not observe any significant decrease in HNF abundance after the aeration (data not shown). In addition, a sample from the surface was deoxygenated for $2 \mathrm{~h}$ with $\mathrm{N}_{2}$ gas to 16 at. sat. $\%$, and then the HNF grazing rate was measured as above. We also measured temperature effects on HNF grazing rates for both surface and hypoxic microaerobic samples by employing the in situ temperature, and temperatures 4 to $6^{\circ} \mathrm{C}$ lower and higher than the in situ temperature. $Q_{10}$ values were calculated according to Caron et al. (1986).

Other analyses. Depth profiles of water temperature and salinity were measured by a CTD. The euphotic depth was estimated by multiplying the Secchi depth by 2.7. Analysis of variance (ANOVA), $t$-test analyses and multiple regression were performed using SPSS for Windows (version 8.0, SPSS Inc.). To test whether the relation ships between bacterial abundance and grazing rates in the oxic and hypoxic layers were identical, multiple regression analyses were performed by a stepwise regression method. The adopted model was: $Y=\beta_{0}+\beta_{1} X+\beta_{2} Z+\beta_{3} X Z$, where $Y$ is the dependent and $X$ the independent variable. We assigned different values to $Z$ for different zones (oxic: 0; hpoxic: 1). All variables were common-log transformed. 

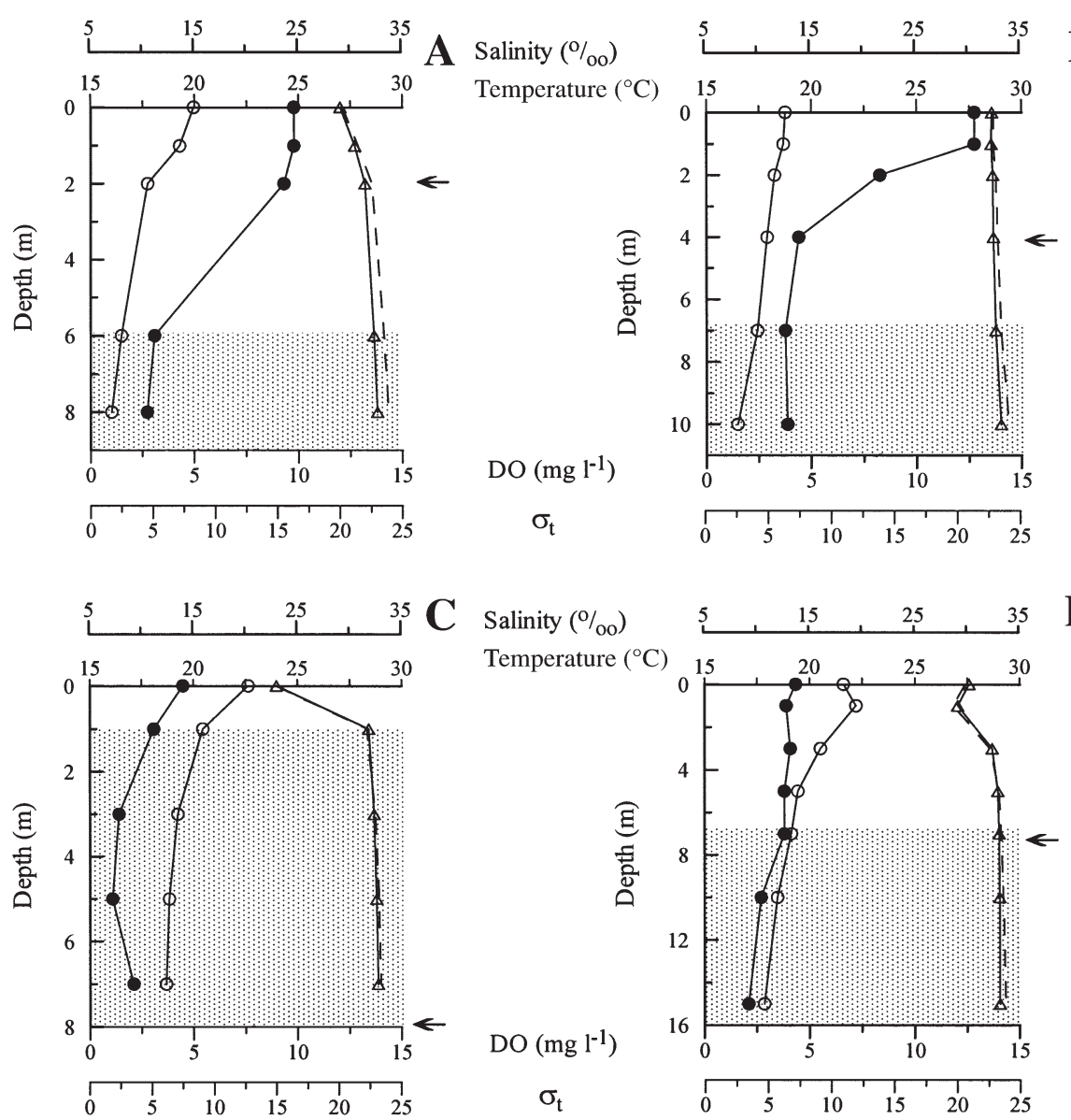

D
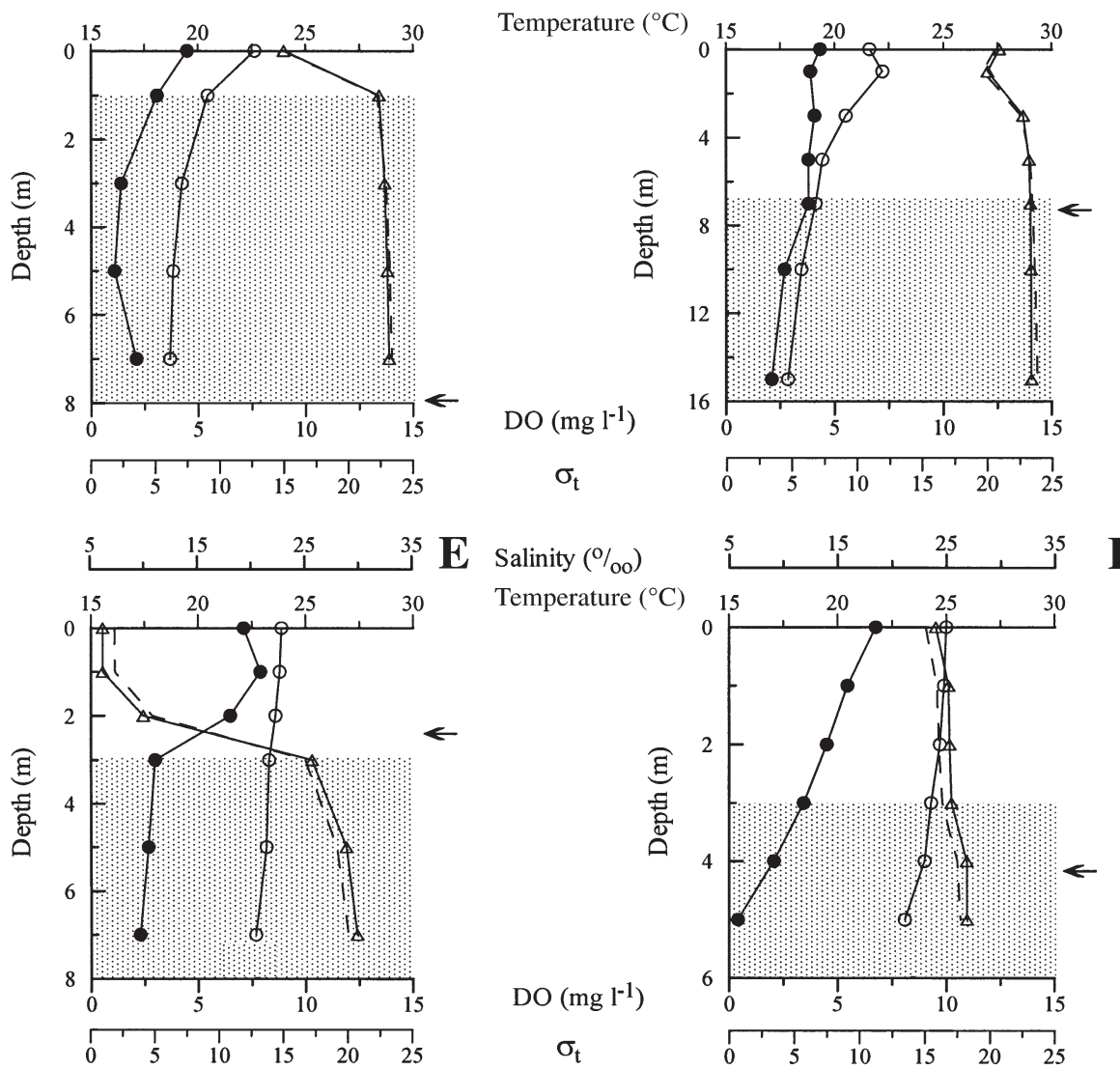

Fig. 2. Vertical distributions of hydrographical parameters measured at Stns B and D in summer 1999. (A,B) Stns B and D on 26 May, respectively. (C,D) Stns B and D on 19 June, respectively. (E) Stn B on 1 August. (F) Stn B on 25 August. (O) Temperature; $(\Delta)$ salinity; $(\bullet)$ dissolved oxygen (DO) concentration; dashed line: $\sigma_{\mathrm{t}}$. Arrow: euphotic depth. Shaded area represents the hypoxic zone. Error bars are less than the size of the symbol

\section{RESULTS}

\section{Hydrography and dissolved oxygen concentration}

During the summertime, low-salinity warm water was found in the surface layer (a 1 to $4 \mathrm{~m}$ thick layer,
Fig. 2) in the study site. Temperature in the surface layer gradually increased from between 17.8 and $20.0^{\circ} \mathrm{C}$ in May 1999 and to between 24.7 and $25.0^{\circ} \mathrm{C}$ in late August 1999. Temperature in the hypoxic zone also gradually increased from between 16.1 and $17.5^{\circ} \mathrm{C}$ in May and to between 23.1 and $24.3^{\circ} \mathrm{C}$ in late 

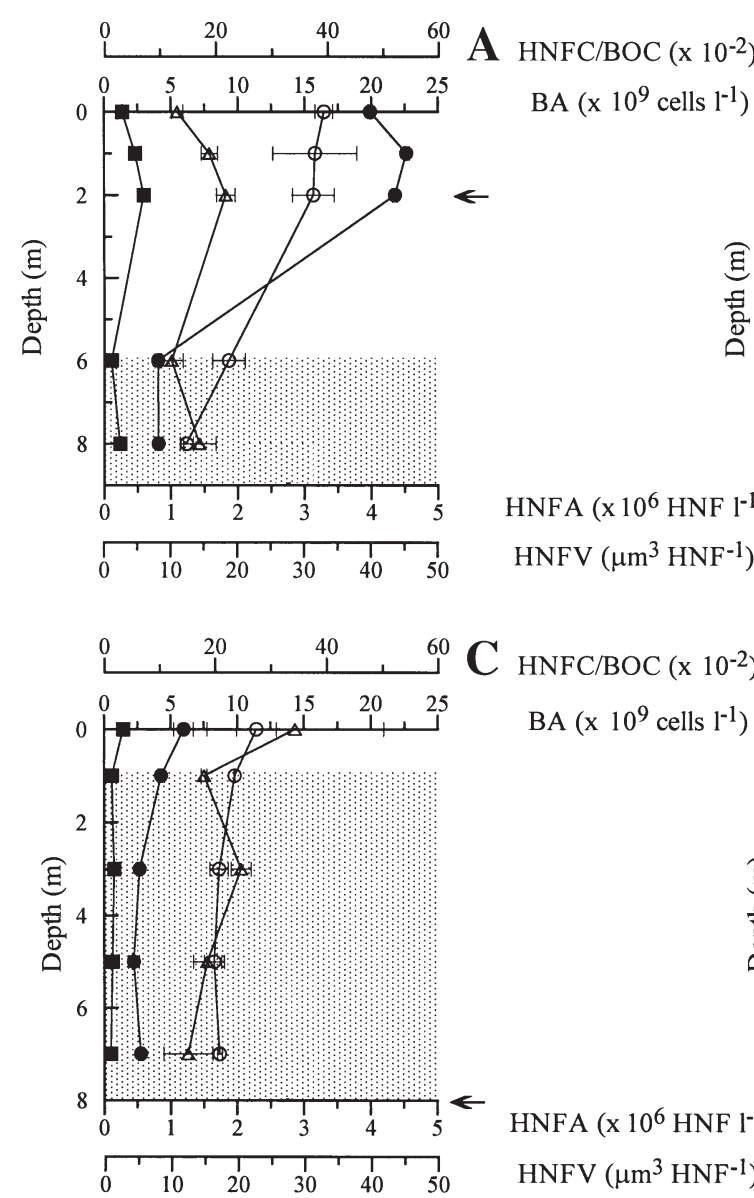

C $\operatorname{HnfC/BOC}\left(x 0^{-2}\right)$

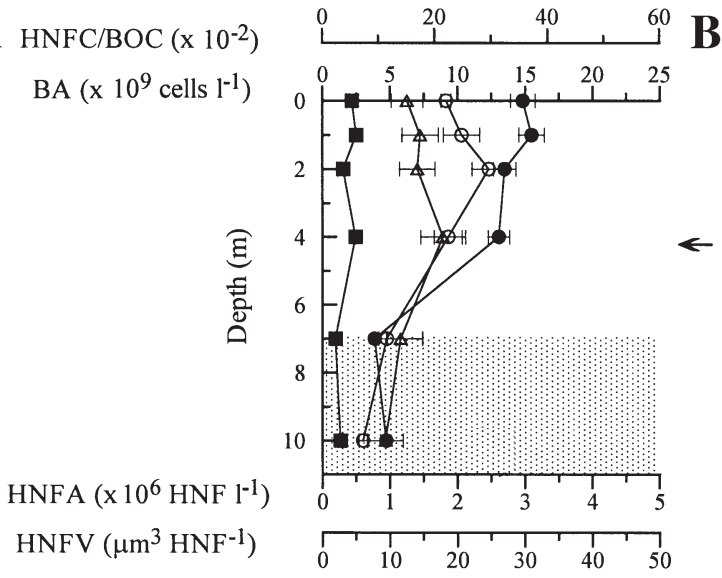

HNFA (x $\left.10^{6} \mathrm{HNF}^{-1}\right)$ $\operatorname{HNFV}\left(\mu \mathrm{m}^{3} \mathrm{HNF}^{-1}\right)$

B
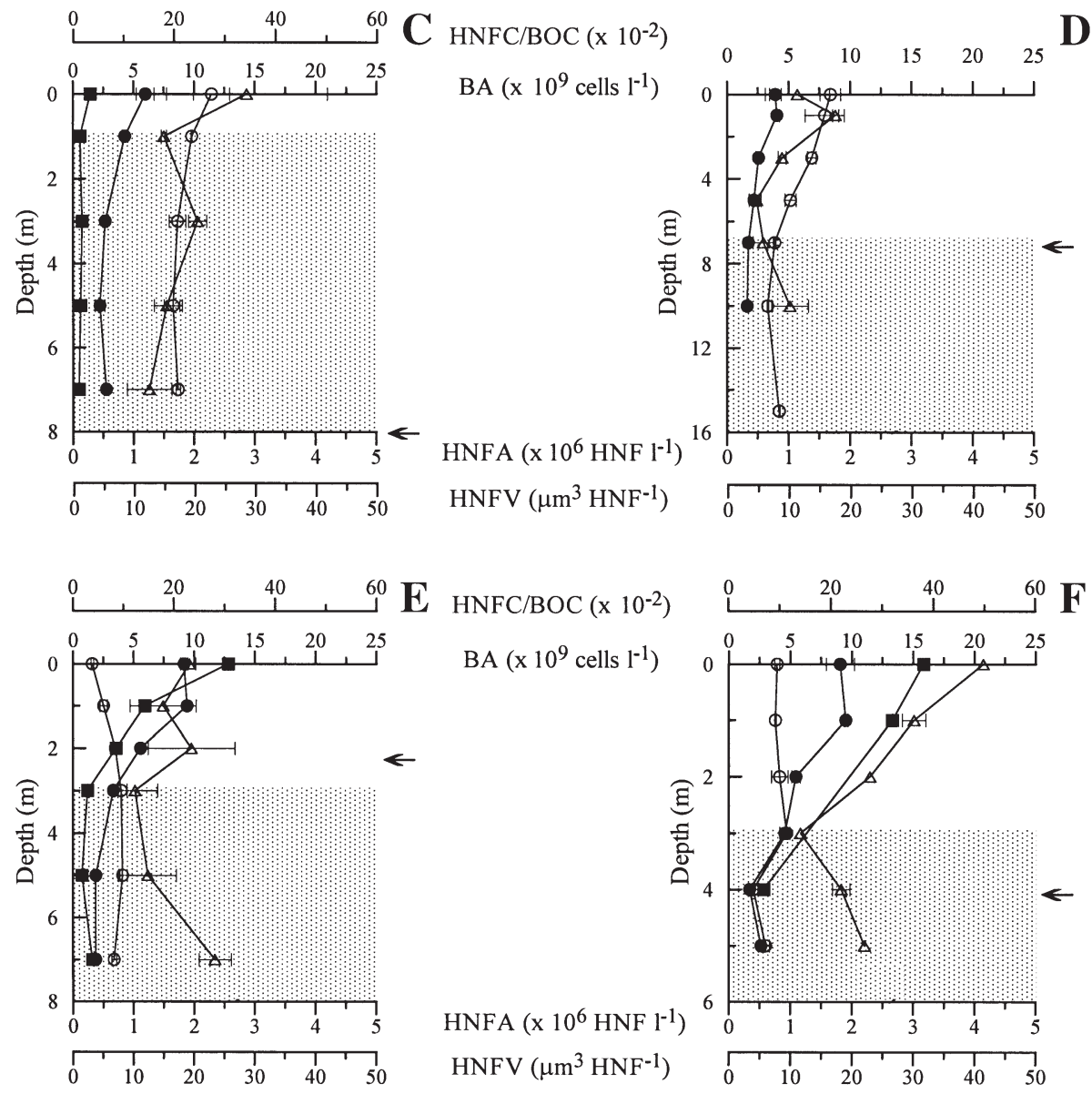

Fig. 3. Vertical distributions of bacterial abundance (BA, o), HNF abundance (HNFA, $\bullet$ ), HNF biovolume (HNFV, $\triangle$ ), and carbonbiomass ratios of HNF to bacteria (HNFC/BOC, $\mathbf{m}$ ). Sampling stations and dates are the same as in Fig. 2. Error bars represent $1 \mathrm{SD}$. When bars are not shown, $1 \mathrm{SD}$ is less than the size of the symbol

August. Salinity in the surface layer ranged from 24.1 to $32.9 \mathrm{psu}$, except on 1 August, when it was unusually low (6.1 to $10.0 \mathrm{psu}$, Fig. 2E) following heavy rains (268 $\mathrm{mm}$ rainfall in the study area, $2 \mathrm{~d}$ before). Salinity in the hypoxic zone remained within 31.1 to 32.9 psu in May and June, but in August salinity decreased to between 24.9 and 29.8 psu, presumably due to partial mixing with much less saline (6.1 to $10.0 \mathrm{psu}$ ) surface water. DO concentration tended to rapidly decrease below the euphotic zone. When the hypoxic zone intruded into the euphotic zone (Fig. 2C,D,F), surface DO concentration was low (3.8 to $6.8 \mathrm{mg} \mathrm{l}^{-1}$ ) and 

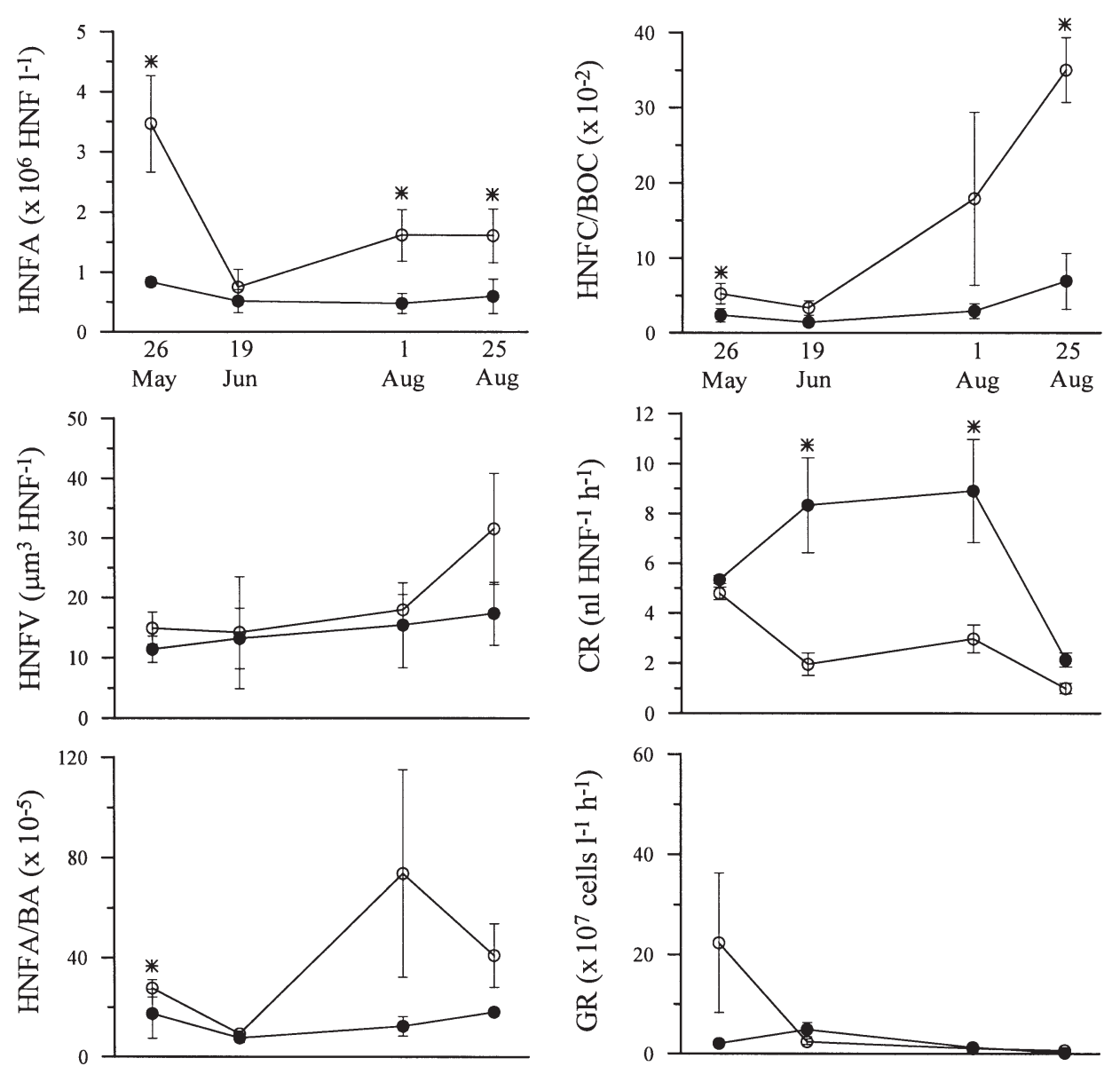

Fig. 4. Temporal variations of microbiological parameters during the study period. Samples were collected from hypoxic $(\bullet)$ and oxic ( $($ ) layers. Stars represent significant difference between oxic and hypoxic samples $(p<0.05)$. HNFA: HNF abundance; HNFV: HNF biovolume; HNFA/BA and HNFC/BOC: abundance and biomass ratios of HNF to bacteria, respectively; CR: clearance rate; GR: grazing rate. Error bars represent $1 \mathrm{SD}$. When bars are not shown, $1 \mathrm{SD}$ is less than the size of the symbol

decreased linearly with depth. In late August (at $6 \mathrm{~m}$ depth at Stn B), micro-aerobic conditions $\left(0.22 \mathrm{mg} \mathrm{O}_{2}\right.$ $\mathrm{l}^{-1}$ ) were observed (data not shown).

\section{Abundances of bacteria and HNF and biovolumes of $\mathrm{HNF}$}

In May and June, a maximum bacterial abundance (8 to $16 \times 10^{9}$ bacteria $1^{-1}$, Fig. 3) was observed in the surface (top $2 \mathrm{~m}$ layer). However, in August, maximal bacterial abundance ( 4 to $5 \times 10^{9}$ bacteria $\mathrm{l}^{-1}$ ) was present at the oxic/hypoxic boundary. Bacterial abundance in the hypoxic zone $\left(2\right.$ to $10 \times 10^{9}$ bacteria $\mathrm{l}^{-1}$ ) was lower than in the surface layer (4 to $16 \times$ $10^{9}$ bacteria $\mathrm{l}^{-1}$ ), except in early August when bacterial abundance was low in the surface layer (1 to $3 \times$ $10^{9}$ bacteria $\mathrm{l}^{-1}$ ) probably due to low salinity (6.1 to $10.0 \mathrm{psu}$ ) at that time. HNF abundances were generally lower in the hypoxic zone $\left(0.3\right.$ to $1 \times 10^{6} \mathrm{HNF}$ $\left.\mathrm{l}^{-1}\right)$ than in the surface layer $\left(0.4\right.$ to $5 \times 10^{6} \mathrm{HNF}^{-1}$, Figs. 3 \& 4). The maximum HNF abundance was found in the top $1 \mathrm{~m}$ layer and it then decreased with depth. Mean HNF biovolumes (generally 10 to $20 \mu^{3}$ ) were statistically similar ( $t$-test; $\left.\mathrm{p}>0.05\right)$ between the surface and hypoxic layers, although in late August surface HNF had on average ca. 2-fold greater mean biovolume (23 to $42 \mu^{3}$ ) than those of hypoxic HNF (Fig. 4).

\section{Abundance and biomass ratios of HNF to bacteria}

Ratios of HNF-to-bacterial abundance varied from 6 to $31 \times 10^{-5}$ in the hypoxic zone, and those in the surface usually ranged from 7 to $33 \times 10^{-5}$, with some higher values (46 to $115 \times 10^{-5}$ ) observed in August (Fig. 4). Biomass-carbon ratios of HNF-to-bacteria varied within a narrow range of 1.0 to $6.9 \times 10^{-2}$ in the hypoxic zone. Compared to biomass ratios of 

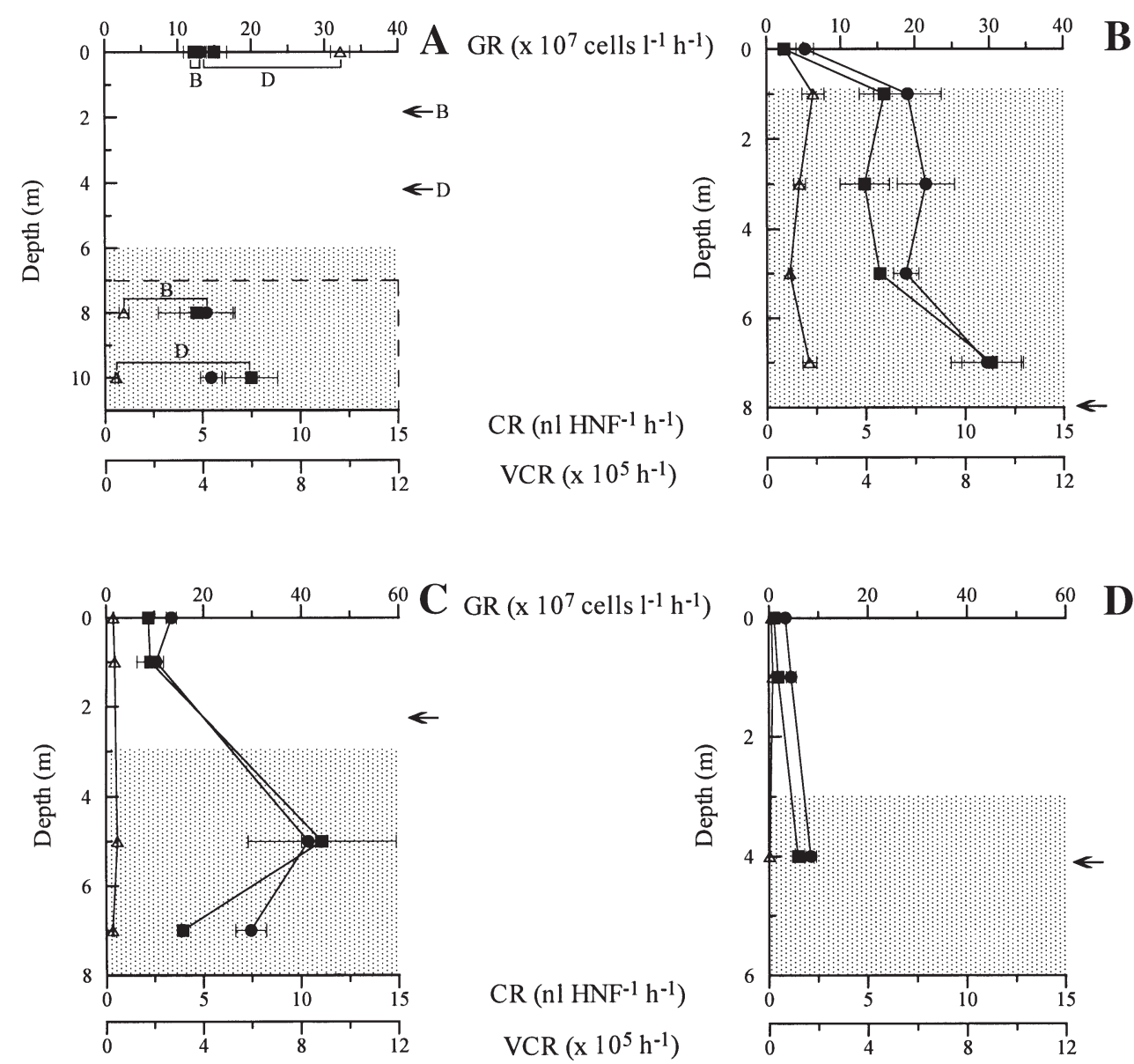

Fig. 5. Vertical distributions of HNF grazing rate $(\mathrm{GR}, \Delta)$, clearance rate $(\mathrm{CR}, \bullet)$, and volume-specific clearance rate (VCR, $\bullet)$. (A) B and D denote variables from sampling Stns B and D, respectively, on 26 May. Shaded area and area marked with dashed line represent the hypoxic layer in Stns B and D, respectively. (B,C,D) Stn B on 19 June, 1 August, and 25 August, respectively. Euphotic depth was marked with an arrow. Error bars represent 1 SD. When bars are not shown, 1 SD is less than the size of the symbol

HNF-to-bacteria in the hypoxic zone, those ratios in the surface were on average 2- to 3-fold and up to 8fold higher in May to June and August, respectively (Fig. 4).

\section{HNF per cell clearance rates and grazing rates}

Per cell clearance rates in surface layer varied within a narrow range of 0.9 to $5.0 \mathrm{nl} \mathrm{HNF}^{-1} \mathrm{~h}^{-1}$ (Fig. 5). Clearance rates of hypoxic HNF were similar to those in the surface layer in May, but tended to be higher in the hypoxic zone in June and August (Fig. 4). In late August, the clearance rate in the hypoxic zone was lowest ( $2 \mathrm{nl} \mathrm{HNF}^{-1} \mathrm{~h}^{-1}$ ). HNF grazing rates (12.5 to 32.2 $\times 10^{7}$ bacteria $\mathrm{l}^{-1} \mathrm{~h}^{-1}$ ) were highest at the surface in May 1999, intermediate $\left(2.5 \times 10^{7}\right.$ bacteria $\left.\mathrm{l}^{-1} \mathrm{~h}^{-1}\right)$ in June and low ( 0.6 to $1.2 \times 10^{7}$ bacteria $\left.\mathrm{l}^{-1} \mathrm{~h}^{-1}\right)$ in August (Fig. 5). In the hypoxic zone, grazing rates $(0.1$ to $6.3 \times$ $10^{7}$ bacteria $\mathrm{l}^{-1} \mathrm{~h}^{-1}$ ) were statistically similar ( $t$-test, $\mathrm{p}>$
0.05) to those in surface layer (Fig. 4). Interestingly, biovolume-specific HNF clearance rates were either similar or higher in the hypoxic zone compared to those in the surface (Fig. 5). Volume-specific HNF clearance rates ranged from 1.2 to $8.9 \times 10^{5} \mathrm{~h}^{-1}$ in the hypoxic zone and 0.2 to $4.5 \times 10^{5} \mathrm{~h}^{-1}$ in the surface. In the hypoxic zone, the lowest volume-specific HNF clearance rate $\left(1.2 \times 10^{5} \mathrm{~h}^{-1}\right)$ was observed in late August.

\section{Interrelationships among microbial and environmental variables}

HNF grazing rates significantly correlated with bacterial abundance in both surface and hypoxic layers with the same slope of $1.61\left(r^{2}=0.70, p<0.001\right.$; Fig. 6). In the hypoxic zone, HNF grazing rates positively correlated with salinity $\left(\mathrm{r}^{2}=0.62, \mathrm{p}=0.01, \mathrm{n}=9\right.$; data not shown). 


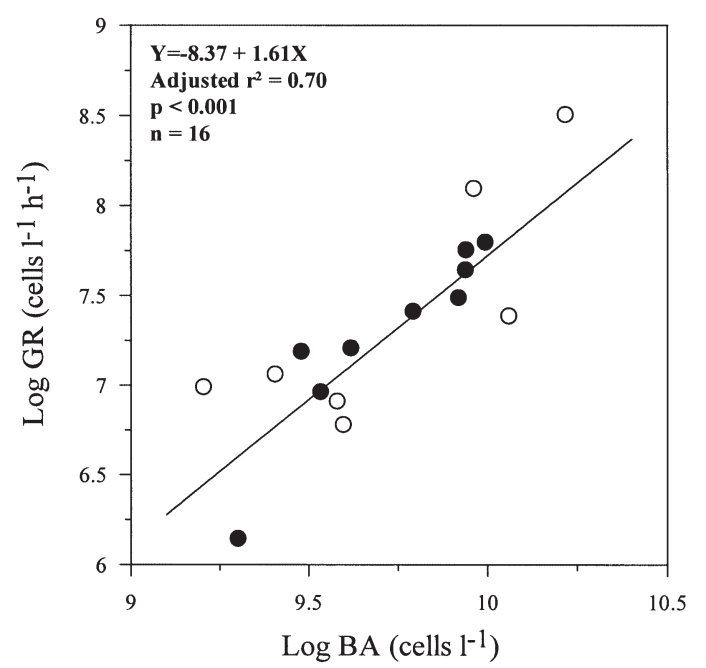

Fig. 6. A scatter plot of bacterial abundance (BA) vs grazing rate (GR). Samples were from oxic $(0)$ and hypoxic $(\bullet)$ layers. A multiple regression analysis showed that the relationships between the 2 variables in 2 layers were identical

\section{Aeration and deoxygenation experiments}

Aerating the hypoxic samples (15 to 35 at. sat. \%) with filtered air for $<2 \mathrm{~h}$ increased DO to near saturation. Grazing rates in aerated samples were statistically similar ( $t$-test, $\mathrm{p}>0.05$, Fig. 7A) to those of controls, indicating that hypoxic HNF were not susceptible to air saturation. In addition, the grazing rate in the micro-aerobic sample $\left(0.22 \mathrm{mg} \mathrm{O}_{2} \mathrm{l}^{-1}\right)$ was not significantly different from the aeration-treated sample (Fig. 7A). We tested whether HNF in the surface layer were affected by hypoxic conditions. Deoxygenating a surface sample with pure $\mathrm{N}_{2}$ gas for $2 \mathrm{~h}$ decreased DO to 16 at. sat. \%, but no significant change in grazing rate was detected ( $t$-test, $\mathrm{p}>0.05$, Fig. 7A). Thus, surface HNF seemed to be non-susceptible to the decrease in DO concentration.

\section{Temperature responses of $\mathrm{HNF}$}

Temperature responses of HNF in the surface and hypoxic zones seemed to be different: In the surface sample, a decreased grazing rate was observed at lowered temperature (ANOVA, p < 0.05, Fig. 7B). In the hypoxic sample, no significant changes in grazing rates were observed at both lowered and increased temperatures (ANOVA, p > 0.05). However, grazing rates were significantly different between the 2 temperature-treated samples (ANOVA, $\mathrm{p}<0.05$ ). $Q_{10}$ values calculated for HNF grazing rates for the temperature ranges for hypoxic and surface samples were 1.6 and 3.2, respectively (Fig. 7B). Temperature re- sponse of HNF from the micro-aerobic sample was similar to that from the hypoxic zone, and the $Q_{10}$ value for a temperature range of 17 to $28^{\circ} \mathrm{C}$ (1.8) was also similar to that obtained from the hypoxic zone (Fig. 7C). However, in the surface sample, no significant differences in grazing rates for 3 different temperatures were observed (Fig. 7C).

\section{DISCUSSION}

Significant observations of this study were that biovolume-specific HNF clearance rates and per cell clearance rates were similar or higher in the hypoxic zone compared to those in the surface zone. Thus, a similar or higher efficiency of prey capture (EcclestonParry \& Leadbeater 1994) seems to be present in HNF in the hypoxic zone compared to HNF in the surface zone. Seemingly, low DO conditions $(0.22$ to $3.87 \mathrm{mg}$ $\mathrm{O}_{2} \mathrm{l}^{-1}$ ) did not restrict HNF grazing activities.

For comparison purposes, unfortunately, no information exists for HNF activity measurements in hypoxic marine ecosystems. In micro-aerophilic water in Lake Vechten, HNF ingestion rates of 2 to 17 bacteria $\mathrm{HNF}^{-1}$ $\mathrm{h}^{-1}$ were reported (Bloem \& Bär-Glissen 1989). To compare with them, our HNF grazing rates are converted to HNF ingestion rates by dividing grazing rates by HNF abundance. Our range of HNF ingestion rates (4 to 102 bacteria $\mathrm{HNF}^{-1} \mathrm{~h}^{-1}$ ) in the hypoxic zone is much larger than, although somewhat overlapping with, that found in Lake Vechten. An estimate of HNF ingestion rate in the micro-aerobic zone in this study (9 bacteria $\mathrm{HNF}^{-1} \mathrm{~h}^{-1}$ ) is within the range reported for the microaerophilic samples by Bloem \& Bär-Glissen (1989). The high ingestion rates of HNF in the hypoxic zone (17 to 102 bacteria $\mathrm{HNF}^{-1} \mathrm{~h}^{-1}$ ) in May, June and early August mainly seemed to be due to high bacterial abundance $\left(3.3\right.$ to $\left.9.8 \times 10^{9} \mathrm{l}^{-1}\right)$, because per cell clearance rates at that time were 5.2 to $11.1 \mathrm{nl} \mathrm{HNF}^{-1}$ $\mathrm{h}^{-1}$ typical to marine HNF (Andersen \& Fenchel 1985). The active ingestion of HNF in the hypoxic zone suggests that a microbial loop operates actively in the hypoxic zone as in the surface zone. Estimated turnover times of bacterial abundance due to HNF grazing in the hypoxic zone ranged from 6.5 to $15.8 \mathrm{~d}$ from May to early August, corresponding to 4.5 to $43.8 \%$ of bacterial production (B.C.C. unpubl. data). They became much longer in late August (83.3 d, corresponding to $0.1 \%$ of bacterial production), indicating reduced HNF activities at that time in spite of high bacterial production (B.C.C. unpubl. data). The presence of diverse bacterivorous ciliates in the hypoxic zone are well known (Fenchel et al. 1990). Therefore, a substantial fraction of bacterial production might also be grazed by ciliates in the hypoxic 

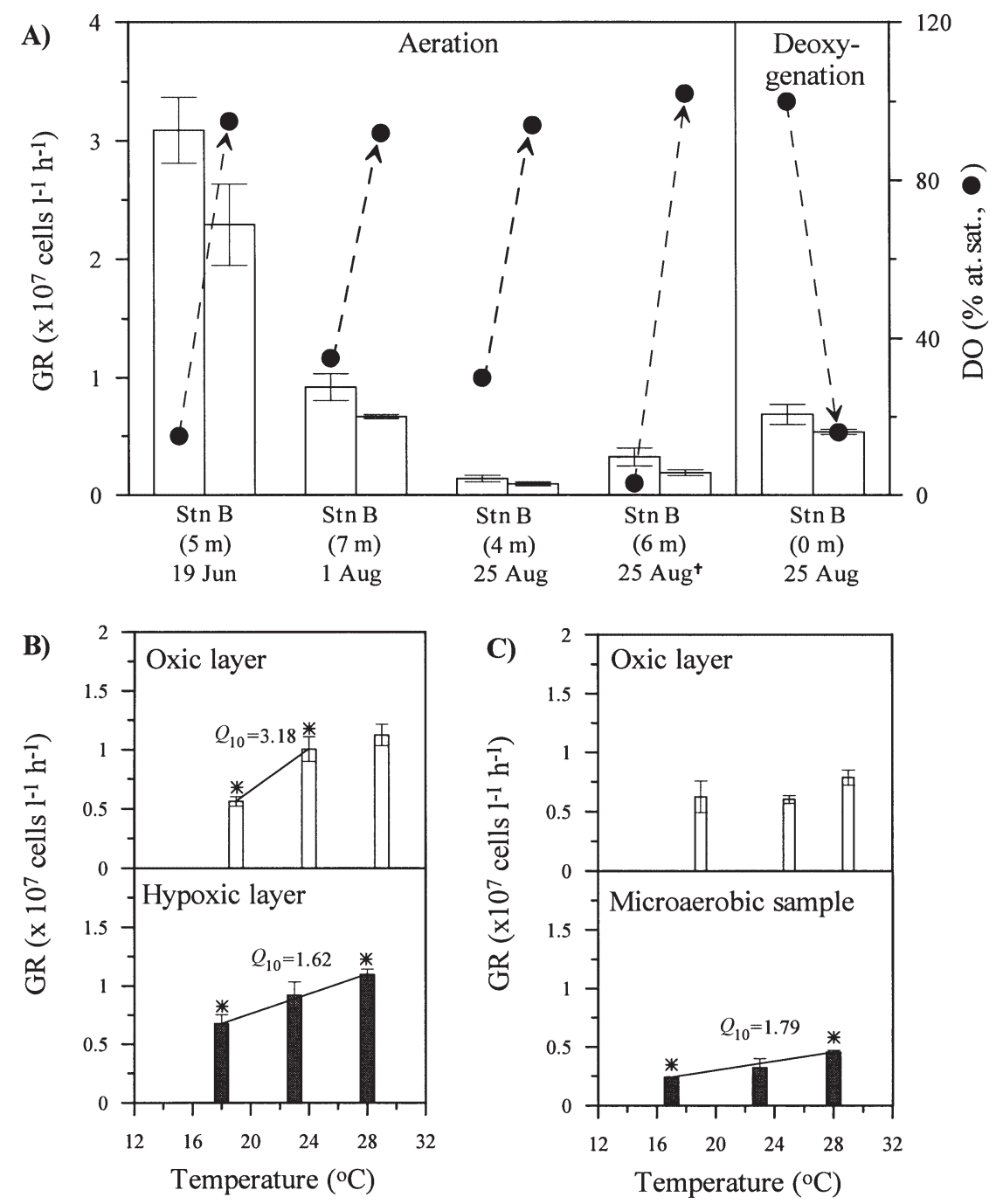

Fig. 7. (A) Responses of HNF grazing rate (GR) to change of dissolved oxygen (DO) concentration. Samples from hypoxic and micro-aerobic zones $(+)$ were aerated by particle-free filtered air. In addition, a sample from the surface was de-oxygenated by pure $\mathrm{N}_{2}$ gas to reduce DO concentration. Control and treatment were not significantly different ( $\left.p>0.05\right)$ in all samples. In parentheses, sampled depths are indicated. (B,C) Responses of HNF GR to different temperatures. Samples were from 1 August (B) and 25 August (C). The bars represent the mean value for each temperature. The error bars are $1 \mathrm{SD}$. Each $Q_{10}$ value was calculated for the ranges of temperature marked with stars

zone. In addition, viruses could be a significant agent of bacterial mortality in the hypoxic zone (B.C.C. unpubl. data). Estimates of HNF growth, based on grazing rates, HNF abundance, gross growth assimilation efficiency of $30 \%$ (Fenchel 1982a), HNF biovolumes, and the carbon-to-biovolume ratio of $220 \mathrm{fg} \mathrm{C}$ $\mu \mathrm{m}^{-3}$ (Børsheim \& Bratbak 1987), were calculated. HNF doubling times were estimated to be 0.2 to $0.9 \mathrm{~d}$ except in late August (20.3 d). Thus, HNF in the hypoxic zone generally seem to grow well. These dynamic activities of hypoxic HNF might be important in the energy flow in the hypoxic zone. HNF, actively grazing on bacteria, in the hypoxic zone would channel energy and materials bound in bacteria to ciliates (and possibly other life forms). HNF grazing in the hypoxic zone on bacteria might also vitalize the hypoxic system's function by stimulating bacterial growth by releasing essential, limiting nutrients immobilized in bacteria as in both aerobic (Fenchel \& Harrison 1976) and anaerobic environments (Biagini et al. 1998).

Speculation about the mode of metabolism in HNF in the hypoxic zone is interesting. Comparisons of per cell clearance rates in the surface and hypoxic zones would not tell whether HNF in the hypoxic zone respired aerobically. For example, an anaerobic ciliate for a similar biovolume has a maximum clearance rate similar to the surface/oxic one (Massana \& Pedrós-Aliós 1994). Thus, 
in this respect, non-susceptibility of hypoxic HNF to DO saturation was noteworthy (Fig. 7A). Non-susceptibility of hypoxic HNF to DO saturation suggests that microaerophilic HNF were not dominant in $\mathrm{HNF}$ assemblages in our samples from the hypoxic zone and even in our micro-aerobic sample. If micro-aerophilic HNF were dominant, grazing rates might be reduced upon exposure to oxygen saturation. Further, higher $\mathrm{pO}_{2}$ is believed to cause reduced survival or growth rates in some micro-aerophilic ciliates (Fenchel et al. 1990). Thus, it seems that dominant HNF assemblages in the hypoxic zone might be unaffected by oxygen saturation and in fact they were aerobes.

In inferring the metabolism of bacterivores, comparisons of bacterivore-to-bacteria biomass ratios in oxic and anoxic layers have proven useful (Fenchel et al. 1990). Fenchel et al. (1990) showed that average biomass ratio of bacterivores (HNF + ciliates) to bacteria was even larger in hypoxic samples than oxic/surface samples, suggesting to us that hypoxic protozoans might have oxic metabolic processes rather than anoxic ones. They inferred anaerobic metabolism in bacterivores when biomass ratios of bacterivores to bacteria in anaerobic samples were much less (i.e. $<1 / 4$ ) than those in aerobic samples. As biomass ratios of HNF to bacteria were only 2- to 3-fold lower in the hypoxic zone than in the surface zone, they consistently support the idea that HNF used an aerobic metabolism. In early August, the ratio between biomass ratios of HNF to bacteria in surface and those in hypoxic zones was ca. 8. However, this would not indicate a possible anaerobic metabolism in hypoxic HNF, as HNF-to-bacteria biomass ratios in the hypoxic zone did not change much from May to early August (Fig. 4). Although we cannot totally exclude the possibility that some HNF in the hypoxic zone might use anaerobic metabolism (e.g. fermentation), microaerophilic HNF might not have been a major fraction of whole communities during the study. Our results of aeration and deoxygenation, and inference of aerobic metabolism in HNF in the hypoxic zone based on biomass ratios of HNF to bacteria support the prediction of the microbial respiration physiology that predict an aerobic metabolism in HNF under the hypoxic conditions (Fenchel \& Finlay 1995).

In the hypoxic zone, bacteria appear to be a key regulatory factor of HNF. Significant correlations of HNF grazing rates with bacterial abundance suggest that increases in bacterial abundance would increase in HNF activities in the hypoxic zone. Increases in bacterial abundance in the hypoxic zone might be possible by several mechnisms: in situ bacterial growth, transports of both free-living and particle-associated bacteria due to vertical mixing, transport of particle- attached bacteria by sinking particles, or bacterial supply by resuspension of sediments. However, we did not observe a positive correlation between bacterial production and HNF grazing rates (data not shown), probably due to their small ranges covered by our samples. Temperature is generally recognized as a regulating factor of HNF grazing rates (Vaqué et al. 1994). Our measurements of $Q_{10}$ values of HNF grazing rate directly indicate that temperature might control HNF activity. In this study, however, there was no significant positive relationship between temperature and HNF grazing rates, presumably because HNF grazing rates were also influenced by both salinity and bacteria in this study. Interestingly, dissimilar $Q_{10}$ values of HNF grazing rates were observed in the surface and hypoxic samples (3.2 vs 1.6, respectively), suggesting that HNF in the surface and hypoxic zones seemed to respond to temperature changes differently and that dominant composition of HNF communities might differ in 2 zones. Our $Q_{10}$ value for HNF grazing rate in the surface was within the range (2.0 to 3.5; Rivkin et al. 1999) reported for grazing by flagellates. However, low $Q_{10}$ values from the hypoxic and micro-aerobic zones (1.6 to 1.8) suggest that HNF in the hypoxic zone would be less affected by varying temperature than HNF in the surface.

In conclusion, HNF in the hypoxic zone with a DO range of 0.22 to $3.87 \mathrm{mg} \mathrm{O}_{2} \mathrm{l}^{-1}$ actively ingested bacteria and thus an active microbial loop operated in the hypoxic zone. It seems that HNF in such conditions were not susceptible to oxygen saturation, and HNF in the surface were not susceptible to hypoxia. Supply of bacteria appeared to mainly regulate HNF in the hypoxic zone.

Acknowledgements. We thank Dr. D. S. Lee (Pusan National University) for CTD data. We thank 3 anonymous reviewers for constructive and helpful comments. This study was supported (in part) by BK 21 project of the Korean Government.

\section{LITERATURE CITED}

Andersen P, Fenchel T (1985) Bacterivory by microheterotrophic flagellates in seawater samples. Limnol Oceanogr 30:198-202

Biagini GA, McIntyre PS, Finlay BJ, Lloyd D (1998) Protozoan stimulation of anaerobic microbial activity: enhancement of the rate of terminal decomposition of organic matter. FEMS Microbiol Ecol 27:1-8

Bloem J, Bär-Glissen MJB (1989) Bacterial activity and protozoan grazing potential in a stratified lake. Limnol Oceanogr 34:297-309

Bloem J, Bär-Glissen MJB, Cappenberg TE (1986) Fixation, counting, and manipulation of heterotrophic nanoflagellates. Appl Environ Microbiol 52:1266-1272

Børsheim KY, Bratbak G (1987) Cell volume to cell carbon 
conversion factors for a bacterivorous Monas sp. enriched from seawaters. Mar Ecol Prog Ser 36:171-175

Caron DA (1986) Effect of temperature on growth, respiration, and nutrient regeneration by an omnivorous microflagellate. Appl Environ Microbiol 52:1340-1347

Cho BC, Na SC, Choi DH (2000) Active ingestion of fluorescently labeled bacteria by mesopelagic heterotrophic nanoflagellates in the East Sea, Korea. Mar Ecol Prog Ser 206:23-32

Choi DH, Na SC, Park YC, Huh SH, Cho BC (1999) Characteristics of microbial abundances in hypoxic water of brackish Lake Shihwa. J Korea Soc Oceanogr 34:236-240

Chung CS, Kim SH, Kang DJ, Park YC, Yoon CH, Hong GH (1999) A study on the evolution of eutrophication in Masan Bay by analyses of pigment derivatives from a sediment column. The Sea, J Korea Soc Oceanogr 4:101-106 (in Korean with English abstract)

Detmer AE, Giesenhagen HC, Trenkel VM, Venne HAD, Jochem FJ (1993) Phototrophic and heterotrophic picoand nanoplankton in anoxic depths of the Central Baltic sea. Mar Ecol Prog Ser 99:197-203

Eccleston-Parry JD, Leadbeater BSC (1994) A comparison of the growth kinetics of six marine heterotrophic nanoflagellates fed with one bacterial species. Mar Ecol Prog Ser 105:167-177

Fenchel T (1982a) Ecology of heterotrophic microflagellates. II. Bioenergetics and growth. Mar Ecol Prog Ser 8:225-231

Fenchel T (1982b) Ecology of heterotrophic microflagellates. IV. Quantitative occurrence and importance as bacterial consumers. Mar Ecol Prog Ser 9:35-42

Fenchel T, Finlay BJ (1995) Ecology and evolution in anoxic worlds. Oxford Univ Press, Oxford

Fenchel T, Harrison P (1976) The significance of bacterial grazing and mineral cycling for the decomposition of particulate detritus. In: Anderson JM, MacFadyen A (eds) The role of terrestrial and aquatic organisms in the decomposition processes. Blackwell Scientific Publications, Oxford, p 285-289

Fenchel T, Kristensen LD, Rasmussen L (1990) Water column anoxia: vertical zonation of planktonic protozoa. Mar Ecol Prog Ser 62:1-10

Fenchel T, Bernard C, Esteban G, Finlay BJ, Hansen PJ, Iversen N (1995) Microbial diversity and activity in a Danish fjord with anoxic deep water. Ophelia 43:45-100

Gast V, Gocke K (1988) Vertical distribution of numbers, biomass and size-class spectrum of bacteria in relation to oxic/anoxic conditions in the Central Baltic Sea. Mar Ecol Prog Ser 45:179-186

González JM, Iriberri J, Egea L, Barcina I (1990) Differential rates of digestion of bacteria by freshwater and marine phagotrophic protozoa. Appl Environ Microbiol 56: 1851-1857

Malakoff D (1998) Death by suffocation in the Gulf of Mexico. Science 281:190-192

Editorial responsibility: Otto Kinne (Editor), Oldendorf/Luhe, Germany
Massana R, Pedrós-Aliós C (1994) Role of anaerobic ciliates in planktonic food webs: abundance, feeding, and impact on bacteria in the field. Appl Environ Microbiol 60: $1325-1334$

Nestlerode JA, Diaz RJ (1998) Effects of periodic environmental hypoxia on predation of a tethered polychaete, Glycera americana: implications for trophic dynamics. Mar Ecol Prog Ser 172:185-195

Paerl HW, Pinckney JL, Fear JM, Peierls BL (1998) Ecosystem responses to internal and watershed organic matter loading: consequences for hypoxia in the eutrophying Neuse River Estuary, North Carolina, USA. Mar Ecol Prog Ser 166:17-25

Park K, Kuo AY, Neilson BJ (1996) A numerical model study of hypoxia in the tidal Rappahannock River of Chesapeake Bay. Estuar Coast Shelf Sci 42:563-581

Pedrós-Aliós C, Calderón-Paz JI, Gasol JM (2000) Comparative analysis shows that bacterivory, not viral lysis, controls the abundance of heterotrophic prokaryotic plankton. FEMS Microb Ecol 32:157-165

Peters F (1994) Prediction of planktonic protistan grazing rates. Limnol Oceanogr 39:195-206

Porter KG, Feig YS (1980) The use of DAPI for identifying and counting aquatic microflora. Limnol Oceanogr 25:943-948

Rassoulzadegan F (1991) Methods for the study of marine microzooplankton. In: Reid PC, Turley CM, Burkill PH (eds) Protozoa and their role in marine processes. Springer Verlag, Berlin, p 39-57

Rivkin RB, Putland JN, Anderson MR, Deibel D (1999) Microzooplankton bacterivory and herbivory in the NE subarctic Pacific. Deep-Sea Res II 46:2579-2618

Seki H (1991) Microbial energetics in marine hypoxic water. Mar Pollut Bull 22:163-164

Seki H, Saido T, Iseki K, Whitney F, Wong CS (1984) Uptake kinetics of microorganisms in the sulfuretum of Saanich Inlet. Arch Hydrobiol 100:73-81

Sherr EB, Sherr BF (1994) Bacterivory and herbivory: key roles of phagotrophic protists in pelagic food webs. Microb Ecol 28:223-235

Sherr BF, Sherr EB, Fallon RD (1987) Use of monodispersed, fluorescently labeled bacteria to estimate in situ protozoan bacterivory. Appl Environ Microbiol 53:958-965

Sherr BF, Sherr EB, Pedrós-Alió C (1989) Simultaneous measurement of bacterioplankton production and protozoan bacterivory in estuarine water. Mar Ecol Prog Ser 54: 209-219

Simon M, Azam F (1989) Protein content and protein synthesis rates of planktonic marine bacteria. Mar Ecol Prog Ser 51:201-213

SPSS Inc. (1997) SPSS for Windows, release 8.0. SPSS, Chicago, IL

Vaqué D, Gasol JM, Marrasé C (1994) Grazing rates on bacteria: the significance of methodology and ecological factors. Mar Ecol Prog Ser 109:263-274

Submitted: March 23, 2001; Accepted: September 20, 2001 Proofs received from author(s): March 14, 2002 